\title{
Multistatistical approaches for environmental geochemical assessment of pollutants in soils of Gadoon Amazai Industrial Estate, Pakistan
}

\author{
Rahib Hussain • Seema A. Khattak • Muhammad Tahir Shah • \\ Liaqat Ali
}

Received: 27 August 2014 / Accepted: 20 January 2015 / Published online: 4 February 2015

(C) The Author(s) 2015. This article is published with open access at Springerlink.com

\begin{abstract}
Purpose The current study was carried out in Gadoon Amazai industrial estate and surrounding areas in order to investigate environmental pollution resulted from various industries. The industries flush their effluents in the surrounding areas without treatment, which can contribute toxic elements and compounds to the soil and also to groundwater of nearby areas. The toxic metals have high potential ecological risk to surrounding environment.

Materials and methods A continuous field survey was conducted to find out flow of industrial effluent in surrounding area. For determining major and toxic metals in soil, a random sampling technique was followed to collect representative samples. A total of 45 samples were collected with 25 soil samples from target areas and 20 samples from the reference areas. For the toxic and heavy metals, $1 \mathrm{~g}$ powder soils (-200 mesh size) was treated with hydrofluoric acid $(10 \mathrm{ml})$, aqua regia $(20 \mathrm{ml})$, and $\mathrm{HCl}(20 \mathrm{ml})$. For the major elements, $0.5 \mathrm{~g}$ samples was treated with hydrofluoric acid $(10 \mathrm{ml})$ and perchloric acid (4 and $2 \mathrm{ml}$ with 2 -h interval). All these soil samples were analyzed for 13 major and toxic metals using Perkin Elmer atomic absorption spectrophotometer (AAS700) equipped with graphite furnace (GF).

Results and discussion The results showed that the mean concentrations $(\mathrm{mg} / \mathrm{kg})$ of toxic, heavy, and major elements in
\end{abstract}

Responsible editor: Zhenli He

Electronic supplementary material The online version of this article (doi:10.1007/s11368-015-1075-9) contains supplementary material, which is available to authorized users.

R. Hussain $(\bowtie) \cdot$ S. A. Khattak $\cdot$ M. T. Shah $\cdot$ L. Ali

National Centre of Excellence in Geology, University of Peshawar, Peshawar, Pakistan

e-mail: rahibpcr@gmail.com target area are $301.6,8.8,152.3,58.8,144.7,359.4,32.5$, 1097, 2508, 786.5, 2572, 4088, and 689.8 for $\mathrm{Cr}, \mathrm{Cd}, \mathrm{Pb}$, $\mathrm{Ni}, \mathrm{Cu}, \mathrm{Zn}, \mathrm{Co}, \mathrm{Fe}, \mathrm{Mn}, \mathrm{Mg}, \mathrm{Na}, \mathrm{Ca}$, and $\mathrm{K}$, respectively. The mean concentration $(\mathrm{mg} / \mathrm{kg}$ ) for toxic and major elements in the reference area are 93.6, 6.1, 35.5, 55.9, 59.1, 116.4, 24.1, 644.3, 1112, 549.0, 1275, 2364, and 995.2 for $\mathrm{Cr}, \mathrm{Cd}$, $\mathrm{Pb}, \mathrm{Ni}, \mathrm{Cu}, \mathrm{Zn}, \mathrm{Co}, \mathrm{Fe}, \mathrm{Mn}, \mathrm{Mg}, \mathrm{Na}, \mathrm{Ca}$, and $\mathrm{K}$, respectively. Several approaches such as pollution load index, ecological risk index, geo-accumulation index, enrichment factor, etc. were applied in order to infer anthropogenic contributions. Conclusions This study indicated that majority of the toxic and major elements contribute to soil pollution, but the toxic metals have high influence on the environment as compared to major elements. Therefore, industrial and commercial activities in the area are the main cause of higher potential ecological risk, as compared to the reference areas. There is strong need for remediation and mitigation measures in the study area, which could help to minimize the environmental pollution produced by the industrial estate.

Keywords Ecological risk index · Geo-accumulation index · Health risk $\cdot$ Pollution load index $\cdot$ Soil toxicity

\section{Introduction}

The sources of metal contents in biosphere and hydrosphere are either anthropogenic or geogenic in nature, but the anthropogenic sources are dominant in causing contamination. The anthropogenic sources are mostly observed in intense industrial areas (Flaten and Steinnes 1999). In these areas, environmental issues related to soil and sediment pollution through toxic and heavy metals received greater attention in both developed and developing countries (Zhang et al. 2007). The 
important impact of soil pollutants on environment is to contaminate the food chain through plants, which ultimately affect human health. The humans can consume much higher amount of toxic metals through various ways, which are carcinogenic, teratogenic, and causing other cardiovascular problems (Steinnes et al. 1989; WHO 2004).

Due to mobility and ingestion of toxic and heavy metals, a variety of health problems have been caused, i.e., vomiting, diarrhea, anemia, nausea, kidney damage, abdominal pain, salivation, and anorexia (Khan et al. 2008; Gaballah and Kilbertus 1998). Beside this, some of the diseases are carcinogenic, which are caused by exposure to toxic and heavy metals. Continuous exposure to toxic metals can lead to fatal health hazard, which can cause rough skin with black dots and arsenical skin lesions, especially on face, arms, and feet of locals (Kazi et al. 2009).

The risk assessment codes are very useful to assess the major and toxic metals in soils and sediments. These codes are classified into two broad categories, i.e., single and integrated assessment indices (Filipssona et al. 2007; Hakanson 1980). Among the single assessment indices, it could be further divided into five categories, i.e., contamination factor, pollution load index, enrichment factor, ecological risk index, and geo-accumulation index. In these indices, the contamination factor is commonly used to find out the variation between the target and reference samples toxicity and their risk for environment (Cabrera et al. 1999; Ameh et al. 2011). Potentially ecological risk is the statistical tool used to determine ecological risk of heavy metals in soils. The toxic response factor is different for different metals, but for some elements, it is neglected because it has no toxicity to environment. However, ecological risk index can measure both toxicity and total concentration of heavy metals in soil and sediments (Sundaray et al. 2011). Geo-accumulation index is a technical method used to quantify the degree of anthropogenic or geogenic contamination and their variation range of concentration in soils. Geo-accumulation index is used to quantify metals in soil and also their health risk grades (Grath et al. 2004; Harikumar et al. 2009).

Studies conducted on Gadoon Amazai Industrial Estate during the period of 1996-2014 reveals high concentrations of major and toxic metals in the soil, plants, and groundwater. Other parameters such as alkalinity, hardness, chloride, chemical oxygen demand, nitrate, sulfate, total dissolved solids, and total suspended solids were also found above their respective permissible limits (Hussain 2014; Baig 1996). Nasrullah et al. (2006) have analyzed the crops of Gadoon Amazai area and found the effect of toxicity in the crops through industrial effluents. These pollutants can cause a variety of chronic and acute diseases. Geochemical investigation of Gadoon and surrounding areas has revealed that geogenic sources possibly release sulfate and nitrate, which accumulate in soil and water bodies and pose threats to local inhabitants (Baig 1996). As the
Gadoon industrial estate was newly established at that time, therefore, Baig's study did not specifically point out the role of industrial estate in contaminating the various resources. Khan et al. (2009) reported that the Gadoon wetland inlets had significant concentration of contaminants than outlets and industrial wastewater could be a source of contamination, but the study was limited to wetland only. In 2014, Amin et al. (2014) conducted a similar study on the Gadoon industrial estate for identification of heavy metals only released by two chemical industries (Sardar and Shafi Chemical Enterprises). They collected only seven samples from one drain and did not analyze whole industrial estate. Therefore, the study of Amin et al. (2014) has not explored the toxicity and ecological risk associated with entire industrial estate.

Risk assessment through different methods is an important tool for identification and management of toxic metals. The industries in the Gadoon Amazai industrial estate (GAIE) discharged a huge amount of wastewater to surrounding soils with greater chances of high concentration of toxic metals. The assessments of ecological and toxicological risks in soil can be attributed to anthropogenic inputs, which can play an important role in assessing soil contamination. The aim of the current study was to evaluate the metal toxicity in soil released by anthropogenic and geogenic activities. The distribution frequency of contaminants in soil and their risk to ecological system was assessed through ecological risk index, geoaccumulation index, pollution load index, and other statistical techniques.

\section{Material and methods}

\subsection{Study area}

The study area is located between latitude $33^{\circ} 5^{\prime} 20^{\prime \prime}$ to $33^{\circ} 7^{\prime}$ $20^{\prime \prime} \mathrm{N}$ and longitude $72^{\circ} 32^{\prime} 45^{\prime \prime}$ to $72^{\circ} 35^{\prime} 45^{\prime \prime} \mathrm{E}$ with an average altitude of $325 \mathrm{~m}$ from sea level (Fig. 1). The study area is bordered to north by Baisak, south by Topi, east by Maini, and west by Gandaf (Khan et al. 2009). Gadoon Amazai Industrial Estate was established in 1986-1987 and comprises of 330 operational units (SDA 2009). The major operational units such as textile, marble, plastic, chemicals, soap and detergent, ghee and cooking oil, and steel industrial units discharged a huge amount of wastewater to the open environment without treatment, which was used for irrigation purposes (Khan et al. 2009).

Gadoon industrial area is part of Chach plain extending from Attock district (Punjab) to southwest of Topi and Swabi, and is a plain, fertile, and moist area (Hussain 2014). The soils are classified as an alluvial plain deposit of Indus River. The geomorphological feature comprises piedmont, flood plain, infilled basin, and local fans. Soil texture is generally sandy and silty and is developed mainly from loess 


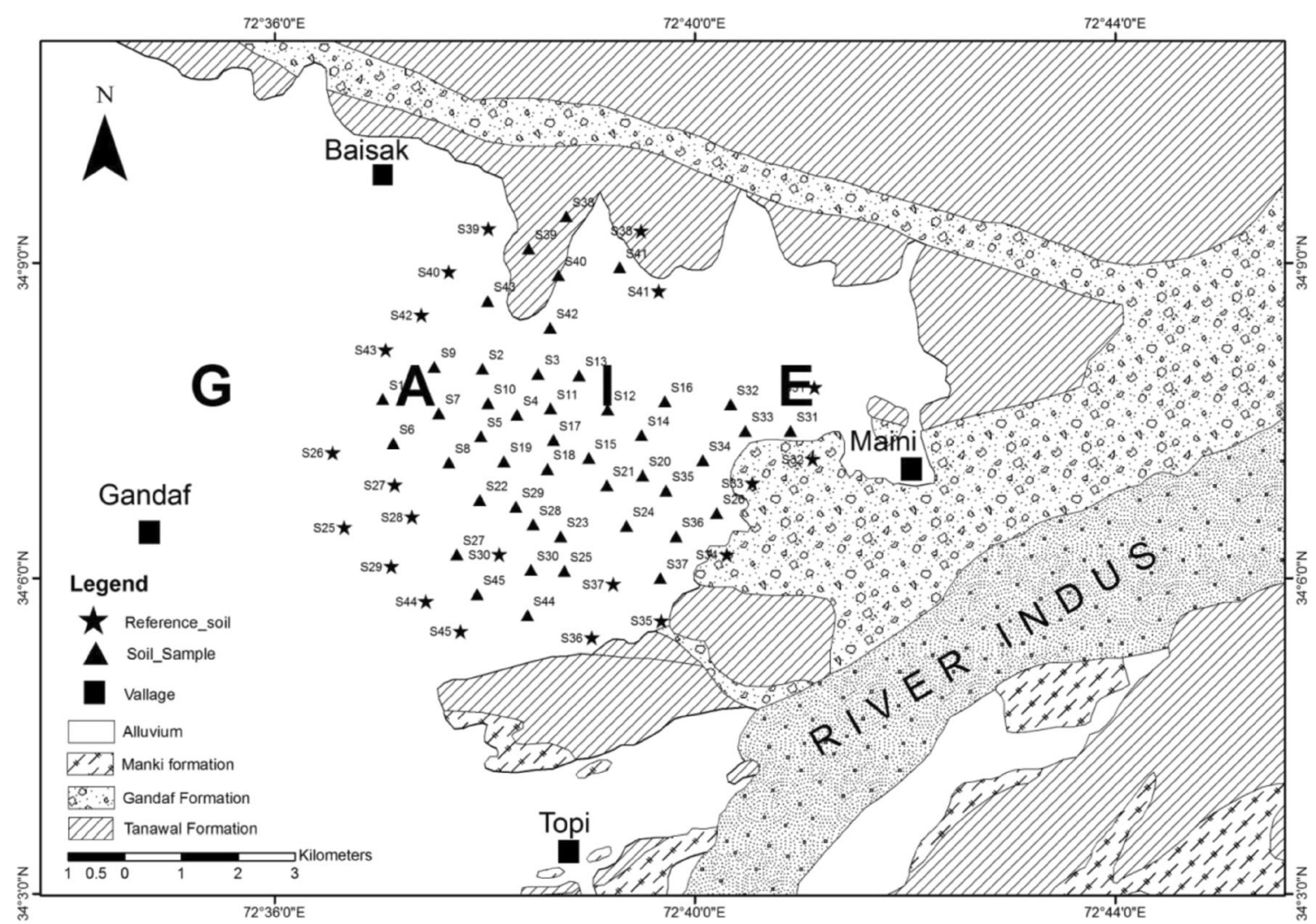

Fig. 1 Map showing location of soil samples collected from Gadoon and surrounding area (modified from Hussain et al. 2004)

material, which is used for irrigation farming (Hussain et al. 1993).

\subsection{Sample collection}

Soil samples were collected from GAIE and surrounding areas in order to assess the contamination between the target and reference areas. In this study, the target areas are considered as those areas, which are mostly irrigated with wastewater flushing by the industries of industrial estate. Reference areas are selected as those areas, which are mostly irrigated with freshwater. These areas have no chance of contamination through any anthropogenic sources.

A random sample technique was applied to collect the soil samples from various locations. Twenty-five samples were collected from the target areas, while 20 samples were collected from the reference areas. These samples were transferred to the Geochemistry Laboratory of the National Centre of Excellence in Geology (NCEG), University of Peshawar, for further processing.

\subsection{Geochemical analysis}

The soil samples were sieved through 2-mm mesh, and the organic matters were removed. These samples were then pulverized to -200 mesh size in the vibrating disc mill. A representative portion of each sample was separated by splitter. For the toxic and heavy metals, $1.00 \mathrm{~g}$ of each soil powdered sample was taken in Teflon beakers. Ten milliliters of hydrofluoric acid (HF) was added to each beaker and heated for $1 \mathrm{~h}$ on hot plate at low heat, and then $20 \mathrm{ml}$ of aqua regia $\left(3 \mathrm{HCl} / 1 \mathrm{HNO}_{3}\right)$ was added to each beaker and heated till the solution got dry. Again, $20 \mathrm{ml}$ of $2 \mathrm{NHCl}$ was added and heated for a while and then the digested contents were filtered through a no. 42 Whatman filter paper into 50-ml volumetric flasks (Macalalad et al. 1988; Jeffery and Hutchison 1986). For major elements, $0.5 \mathrm{~g}$ of each sample was taken in Teflon beakers. Ten milliliter of HF and then $4 \mathrm{ml}$ of perchloric acid $\left(\mathrm{HClO}_{4}\right)$ were added to each beaker and heated for one hour at low heat on hot plate. After $1 \mathrm{~h}, 2 \mathrm{ml}$ of perchloric acid was added again and heated till a paste was obtained in each beaker. After obtaining paste, $4 \mathrm{ml}$ of perchloric acid was added again and heated for a while. The contents of each beaker were filtered through a no. 42 Whatman filter paper in 250-ml volumetric flasks (Jeffery and Hutchison 1986). In order to verify the analysis, the certified reference geological standards (i.e., G-2, AGV1, and W-2) were also treated by the same methods. The final solutions, obtained after digesting the soil samples, were then aspirated through atomic absorption spectrophotometer (Perkin Elmer 700) under standardized conditions, and the concentrations of major, toxic, and heavy metals were determined in the samples collected from target and reference areas and the certified reference geological standards. The chemical and reagents used were of research grade. The 
precision and reproducibility were found within the confidence limit of $90 \%$.

\section{Geo-statistical analysis}

In the statistical technique, indices were applied to assess the contamination load in soil. There are two types of indices, i.e., single index and integrated index. Integrated indices are the geo-statistical techniques applied on aggregate elemental contaminants rather than single elements pollution, but each of integrated indices could be obtained from single pollution load index as suggested by Caeiro et al. (2005) and Qingjie and Jun (2008). The SSPS software was used for statistical analyses.

\subsection{Contamination factor}

Contamination factor $(\mathrm{CF})$ is also called single pollution index (PI). Contamination factor is the quotient obtained by dividing the concentration of metals related to the target area by reference area. Their results are mostly associated with single pollution load, while their n-root was used for integrated pollution load index. The contamination factor can be calculated through the following formula as suggested by Harikumar et al. (2009).

$\mathrm{CF}=\frac{\mathrm{Cn}}{\mathrm{Bn}}$

In above equation, " $\mathrm{Cn}$ " is the concentration of metals in the target area, and "Bn" is the metals concentration of the reference area.

\subsection{Geo-accumulation index}

Geo-accumulation index is used to quantify the degree of anthropogenic or geogenic accumulated pollutant loads in soil and can be determined through the following formula:

$I_{\text {geo }}=\log _{2}\left(\frac{\mathrm{Cn}}{1.5 \times \mathrm{Bn}}\right)$

where "Cn" and "Bn" are the determined concentration of metals in the target and reference areas, respectively. The factor 1.5 is possible anthropogenic variations of contaminants in reference areas (Lokeshwari and Chandrappa 2006; Fagbote and Olanipekun 2010).

\subsection{Ecological risk factor}

Ecological risk index (ERI) is critical to measure both risk factor and metals concentrations in soil. The potential ecological risk index can be determined through the following formula:

$\mathrm{Er}=\operatorname{Tr} \times \mathrm{CF}$

where "Er" is the potential ecological risk factor/index, "Tr" represents the toxic-response factor, and " $\mathrm{CF}$ " represents contamination factor (measured through Section 3.1). The toxic response values for some of the toxic and trace elements are $\mathrm{As}=10, \mathrm{Cr}=2, \mathrm{Cd}=30, \mathrm{Cu}=5, \mathrm{~Pb}=5, \mathrm{Ni}=5$, and $\mathrm{Zn}=1$ as suggested by Hakanson (1980).

\subsection{Enrichment factor}

The enrichment factor (EF) was calculated for the level of elemental enrichment in soil and sediments in terms of their anthropogenic and geogenic origins. Enrichment factor is a common approach to assess the impacted soil and can be calculated through following formula as suggested by Huu et al. (2010); Atgn et al. (2000):

$\mathrm{EF}=\left(\frac{\mathrm{Cn}}{\mathrm{Cm}}\right) /\left(\frac{\mathrm{Cb}}{\mathrm{Cx}}\right)$

where " $\mathrm{Cn}$ " is the concentration of elements in the target area, and " $\mathrm{Cm}$ " is the rare concentration (lowest possible concentration in the target area) of element in the target area, whereas " $\mathrm{Cb}$ " is the concentration of element in reference area, and " $\mathrm{Cx}$ " is a rare concentration (lowest possible concentration in the reference area) of element in the reference area.

\subsection{Pollution load index}

Pollution load index (PLI) is simple statistical technique used to determine elemental contents in soil beyond the reference concentration and provide comprehensive information about the metals toxicity in respective samples (Tomlinson et al. 1996; Yang et al. 2011). Pollution load index can be determined through the following formula:

$\mathrm{PLI}=\sqrt[\mathrm{n}]{\mathrm{CF} 1 \times \mathrm{CF} 2 \times \mathrm{CF} 3 \ldots \ldots \ldots \ldots \mathrm{CF} n}$

where "PLI" represents the pollution load index, "CF" is the contamination factor, and " $n$ " is the number of elements. The PLI " $>1$ " indicates polluted, while " $<1$ " indicates no pollution. 


\subsection{Weighted average of pollution index ( $\mathrm{PIw}_{\mathrm{avg}}$ )}

Weighted average of pollution index $\left(\mathrm{PIw}_{\mathrm{avg}}\right)$ is a simple statistical technique used for toxic and major elements importance (toxicity) in the target area. A weighted average of pollution index was defined by Qingjie and Jun (2008) and is calculated as:

$\mathrm{PIw}_{\mathrm{avg}}=\sum_{i=1}^{m} \mathrm{WiPi}$

where $\mathrm{Pi}$ is the single pollution index of metals $i$, Wi is the weight of $\mathrm{Pi}$, and $m$ is the count of heavy metals species. The weight values for major and toxic metals are $1-5$ as suggested by Qingjie and Jun (2008). The high values of this index indicate the high toxicity, i.e., 5. As the toxicity decreases, the value also reduces up to 1 . Here, the sum of $\mathrm{PIw}_{\text {avg }}$ was not necessary but just for the sake of expressions.

\section{Results and discussion}

\subsection{Elemental concentrations in soils}

Comparison of the relative concentration of toxic, heavy, and major elements in target and reference areas of GAIE and surrounding areas are given in Table 1, while their respective results for all the samples are given in Table S1 and Table S2 (see Electronic Supplementary Material). The concentrations of all the elements of target area were higher than those of the reference area with greater variation in the relative abundance of most of the elements. The highest and lowest possible variation was found between $\mathrm{Pb}$ and $\mathrm{Ni}$ (76.69 and $4.93 \%$ ), respectively (Table 1). The increasing trend was in the order of $\mathrm{Pb}>\mathrm{Cr}>\mathrm{Zn}>\mathrm{Cu}>\mathrm{Mn}>\mathrm{Na}>\mathrm{Ca}>\mathrm{Fe}>\mathrm{Cd}>\mathrm{Mg}>\mathrm{Co}>\mathrm{K}>$ $\mathrm{Ni}$. Majority of the major elements were in low variation, while toxic and heavy metals had high variation. This variation can be attributed to the variable release of effluents from the industries.

\subsection{Geo-accumulation index}

According to Fagbote and Olanipekun (2010), the intensities for geo-accumulation index (GAI or $I_{\text {geo }}$ ) of element according to their grading, degrees, and values are classified as: grade zero $\left(0<I_{\text {geo }} \leq 1\right)$, which is considered as unpolluted, grade $1\left(1<I_{\text {geo }} \leq 2\right)$ as slightly polluted, grade $2\left(2<I_{\text {geo }} \leq 3\right)$ as moderate polluted, grade $3\left(3<\mathrm{I}_{\text {geo }} \leq 4\right)$ moderate to severely polluted, grade $4\left(4<I_{\text {geo }} \leq 5\right)$ as severely polluted, while grade $5\left(I_{\text {geo }}>5\right)$ as severely to extremely polluted.

The geo-accumulation indices of toxic, heavy, and major elements calculated for the soil of the study areas are given in Table 2. The minimum, maximum, and mean values of geoaccumulation index for each element are graphically presented in Fig. 2. The mean GAI trend for heavy and major elements were $\mathrm{Cr}>\mathrm{Mg}>\mathrm{Ca}>\mathrm{Pb}>\mathrm{Cu}>\mathrm{Zn}>\mathrm{Fe}>\mathrm{Mn}>\mathrm{Na}>\mathrm{Co}>\mathrm{Ni}>$ $\mathrm{Cd}>\mathrm{K}$.

According to GAI, the elemental concentration in the studied soil samples could be categorized as: (1) $\mathrm{Cr}, \mathrm{Mg}$, and $\mathrm{Ca}$ in severely to extremely polluted category; (2) $\mathrm{Pb}$ and $\mathrm{Cu}$ in moderately to severely polluted category; (3) Zn, Fe, and $\mathrm{Mn}$ in moderately polluted category; (4) Co and $\mathrm{Na}$ in slightly

Table 1 Toxic, heavy, and major elements $(\mathrm{mg} / \mathrm{kg})$ in target and reference areas of GAIE

\begin{tabular}{|c|c|c|c|c|c|c|c|c|c|}
\hline & \multicolumn{4}{|c|}{ Target area soil sample, $n=25$} & \multicolumn{4}{|c|}{ Reference area soil, $n=20$} & \multirow{2}{*}{$\begin{array}{l}\text { Variation } \\
\text { Percent }\end{array}$} \\
\hline & Min & Max & Mean & SD & Min & $\operatorname{Max}$ & Mean & SD & \\
\hline $\mathrm{Cr}$ & 110.5 & 485.6 & 301.6 & 102.1 & 1.6 & 352.2 & 93.6 & 88.4 & 68.96 \\
\hline $\mathrm{Cd}$ & 1.25 & 36.5 & 8.8 & 8.6 & 3.9 & 8.35 & 6.13 & 1.2 & 30.34 \\
\hline $\mathrm{Pb}$ & 49.2 & 544.5 & 152.3 & 117.4 & 6.75 & 103.8 & 35.5 & 26.7 & 76.69 \\
\hline $\mathrm{Ni}$ & 21.0 & 119.6 & 58.8 & 24.2 & 25.9 & 95.5 & 55.9 & 19.4 & 4.93 \\
\hline $\mathrm{Cu}$ & 10.5 & 505.0 & 144.7 & 100.3 & 9.5 & 140.0 & 59.1 & 36.2 & 59.15 \\
\hline $\mathrm{Zn}$ & 53.7 & 1450 & 359.4 & 379.7 & 33.7 & 305.0 & 116.4 & 81.3 & 67.61 \\
\hline Co & 9.00 & 97.20 & 32.53 & 17.1 & 10.15 & 33.10 & 24.14 & 6.8 & 25.79 \\
\hline $\mathrm{Fe}$ & 662.1 & 1987 & 1097 & 323.3 & 132.6 & 939.5 & 644.2 & 218.5 & 41.30 \\
\hline $\mathrm{Mn}$ & 976.5 & 6770 & 2508 & 1490 & 372.5 & 4214 & 1112 & 710.9 & 55.66 \\
\hline $\mathrm{Mg}$ & 88.8 & 1524 & 786.5 & 444.3 & 12.21 & 1478 & 549.3 & 342.4 & 30.15 \\
\hline $\mathrm{Na}$ & 1676 & 4324 & 2572 & 576.3 & 772.2 & 1802 & 1275 & 223.3 & 50.43 \\
\hline $\mathrm{Ca}$ & 588 & 7371 & 4088 & 2290 & 294 & 6100 & 2364 & 1357 & 42.17 \\
\hline $\mathrm{K}$ & 94.5 & 970.0 & 689.8 & 192.4 & 413 & 1267 & 995.1 & 219.0 & 7.47 \\
\hline
\end{tabular}

$n$ number of samples, SD standard deviation, Min minimum, Max maximum 
Table 2 Geo-accumulation index for the soil of GAIE and surrounding areas

\begin{tabular}{lllll}
\hline $\mathrm{S} / \mathrm{N}$ & Parameters & Min (Igeo) & Max (Igeo) & Mean (Igeo) \\
\hline 1 & $\mathrm{Cr}$ & 5.525 & 7.664 & 6.974 \\
2 & $\mathrm{Cd}$ & -2.227 & 2.641 & 0.596 \\
3 & $\mathrm{~Pb}$ & 2.281 & 5.749 & 3.911 \\
4 & $\mathrm{Ni}$ & -0.888 & 1.623 & 0.598 \\
5 & $\mathrm{Cu}$ & -0.441 & 5.147 & 3.345 \\
6 & $\mathrm{Zn}$ & 0.087 & 4.842 & 2.829 \\
7 & $\mathrm{Co}$ & -0.758 & 2.675 & 1.095 \\
8 & $\mathrm{Fe}$ & 1.735 & 3.321 & 2.464 \\
9 & $\mathrm{Mn}$ & 0.805 & 3.599 & 2.167 \\
10 & $\mathrm{Mg}$ & 2.357 & 6.459 & 5.504 \\
11 & $\mathrm{Na}$ & 0.533 & 1.901 & 1.151 \\
12 & $\mathrm{Ca}$ & 2.485 & 6.133 & 5.28 \\
13 & $\mathrm{~K}$ & -2.713 & 0.647 & 0.155 \\
\hline
\end{tabular}

polluted category; and (5) $\mathrm{Ni}, \mathrm{Cd}$, and $\mathrm{K}$ in unpolluted category.

\subsection{Enrichment factor}

Majority of geogenic and anthropogenic constituents of toxic and heavy metals in term of their distribution, contribution, and significant threats to living organism can be explained through enrichment factor (Atgn et al. 2000). As the enrichment factor increases the distribution of contaminants also increases. On the basis of enrichment factor six degrees are recognized (Sutherland 2000). If the enrichment factor (EF) is $\leq 1$, it is considered as a background rank, $1-2$ as minimal, $2-5$ as moderate, $5-20$ as significant, and $20-40$ as very high enrichment, while EF above 40 was considered as extreme high enrichment (Huu et al. 2010).

The enrichment factor for $\mathrm{Cr}, \mathrm{Cd}, \mathrm{Pb}, \mathrm{Ni}, \mathrm{Cu}, \mathrm{Zn}, \mathrm{Co}, \mathrm{Fe}$, $\mathrm{Mn}, \mathrm{Mg}, \mathrm{Na}, \mathrm{Ca}$, and $\mathrm{K}$ were $0.02,4.49,0.56,1.28,2.17$, $1.86,1.53,0.36,0.61,0.19,0.92,0.14$, and 3.18 , respectively (Fig. 3). Among these major and toxic elements, i.e., $\mathrm{Cr}, \mathrm{Pb}$,

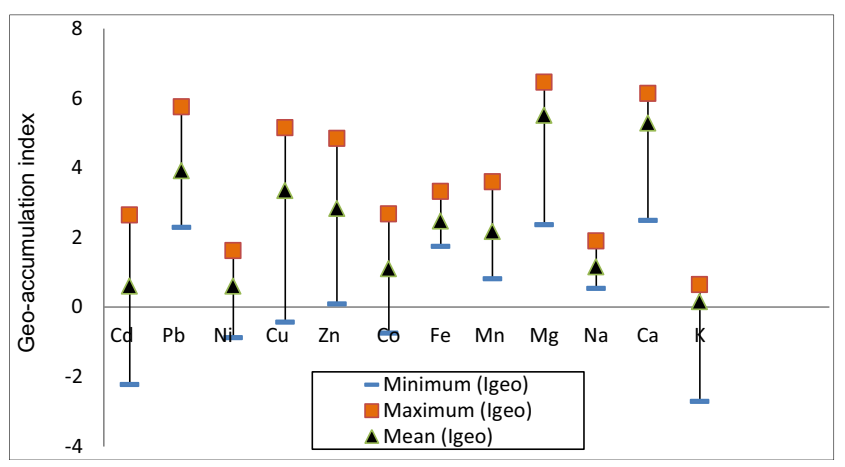

Fig. 2 Geo-accumulation index for toxic and major elements in the soils of GAIE and surrounding areas

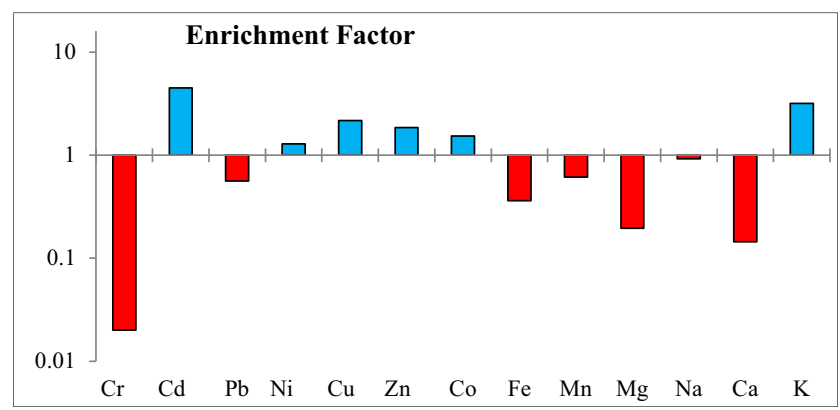

Fig. 3 Enrichment factor $(E F)$ for toxic and heavy metals in the soil of GAIE and surrounding areas

$\mathrm{Fe}, \mathrm{Mn}, \mathrm{Mg}$, and $\mathrm{Ca}$ were in depletion range, while $\mathrm{Cd}, \mathrm{Ni}$, $\mathrm{Cu}, \mathrm{Zn}, \mathrm{Co}$, and $\mathrm{K}$ were enriched in the study area. The enrichment trends for major and toxic metals in the study area were $\mathrm{Cd}>\mathrm{K}>\mathrm{Cu}>\mathrm{Zn}>\mathrm{Co}>\mathrm{Ni}>\mathrm{Na}>\mathrm{Mn}>\mathrm{Pb}>\mathrm{Fe}>\mathrm{Mg}>\mathrm{Ca}$ and $\mathrm{Cr}$, respectively.

\subsection{Ecological risk index}

The ecological risk index (ERI) is used to evaluate the ecological risk degrees for toxic and heavy metals in soils (Hakanson 1980).

The potential ecological risk (Er) and its grading are summarized as. If $\mathrm{Er}$ is $<40$, it is ranked as low risk for environment, if $\mathrm{Er} 40 \leq \mathrm{Er}<80$, it may cause moderate risk, if the values found between $80 \leq \mathrm{Er}<160$, it may cause considerable risk, and if $\operatorname{Er} 160 \leq \mathrm{Er}<320$, it may cause high risk, while $\mathrm{Er} \geq$ 320 is ranked as a very high risk for environment. The ERI was determined mainly for the toxic and heavy metals but also applied for the major elements in term of their compounds, which could be toxic for biological species (Yisa et al. 2012).

The distribution of minimum, maximum, and mean potential ecological risk for environment in the soil samples of the study area showed that $\mathrm{Cr}$ posed high risk to ecological system; while $\mathrm{Pb}$ caused significant risk, $\mathrm{Cd}, \mathrm{Cu}, \mathrm{Mg}$, and $\mathrm{Ca}$ posed a moderate risk (Table 3 ). The remaining elements may have caused low ecological risk to the environment. The decreasing trend of heavy metals in the study area for potential ecological risk to environment were in the order of $\mathrm{Cr}>\mathrm{Pb}>\mathrm{Cd}>\mathrm{Cu}>\mathrm{Zn}>\mathrm{Ni}>\mathrm{Co}$, while the decreasing trend for major elements were $\mathrm{Mg}>\mathrm{Ca}>\mathrm{Mn}>\mathrm{Fe}>\mathrm{Na}>\mathrm{K}$ (Table 3). The ERI has proved to be very useful for heavy and major element pollutants in soil and sediments (Qingjie and Jun 2008). The ERI for the soil of the study area indicated that $7 \%$ of elements posed no ecological risk, $50 \%$ were in low risk, $28 \%$ were in moderate risk, $7 \%$ were in considerable risk, and the remaining $7 \%$ were in very high risk.

\subsection{Pollution load index}

The PLI for all the elements of study area soil are given in Table 4. Pollution load index can be obtained by integrating 
Table 3 Potential ecological risk for environment at GAIE and surrounding area

\begin{tabular}{lllll}
\hline $\mathrm{S} / \mathrm{N}$ & Parameters & Min (Er) & Max (Er) & Mean (Er) \\
\hline 1 & $\mathrm{Cr}$ & 138.1 & 608.3 & 377.038 \\
2 & $\mathrm{Cd}$ & 9.63 & 280.7 & 68.01 \\
3 & $\mathrm{~Pb}$ & 36.44 & 403.3 & 112.82 \\
4 & $\mathrm{Ni}$ & 4.055 & 23.09 & 11.34 \\
5 & $\mathrm{Cu}$ & 5.525 & 265.7 & 76.19 \\
6 & $\mathrm{Zn}$ & 1.593 & 43.02 & 10.66 \\
7 & $\mathrm{Co}$ & 0.887 & 9.576 & 3.205 \\
8 & $\mathrm{Fe}$ & 4.992 & 14.98 & 8.277 \\
9 & $\mathrm{Mn}$ & 2.621 & 18.17 & 6.735 \\
10 & $\mathrm{Mg}$ & 7.686 & 131.9 & 68.09 \\
11 & $\mathrm{Na}$ & 2.170 & 5.601 & 3.331 \\
12 & $\mathrm{Ca}$ & 8.4 & 105.3 & 58.41 \\
13 & $\mathrm{~K}$ & 0.229 & 2.349 & 1.670 \\
Sum of risk index & & 222.4 & 1912 & 805.7 \\
\hline
\end{tabular}

contamination factor. Contamination factor can simply be obtained by the ratio of metal concentration in target and reference areas. The minimum, maximum, and mean values of PLI are $0.96,158.2$, and 21.8 , respectively.

The combined pollution load index was extracted from contamination factor. The decreasing trend of PLI for toxic and heavy metals were found as $\mathrm{Cr}>\mathrm{Pb}>\mathrm{Cu}>\mathrm{Zn}>\mathrm{Co}>$ $\mathrm{Ni}>\mathrm{Cd}$, while the PLI decreasing trend for major elements were noticed as $\mathrm{Mg}>\mathrm{Ca}>\mathrm{Fe}>\mathrm{Mn}>\mathrm{Na}>\mathrm{K}$. The minimum contamination factor showed that $30 \%$ of elements were included within perfection category, $15 \%$ were in baseline level, while the remaining $55 \%$ were in polluted category.

Table 4 Pollution load Index and their derivatives for the soil of GAIE and surrounding areas

\begin{tabular}{llllll}
\hline $\mathrm{S} / \mathrm{N}$ & Parameters & Min (CF) & Max (CF) & Mean (CF) & PLI \\
\hline 2 & $\mathrm{Cr}$ & 69.09 & 304.1 & 188.5 & 158.2 \\
3 & $\mathrm{Cd}$ & 0.321 & 9.360 & 2.267 & 1.896 \\
4 & $\mathrm{~Pb}$ & 7.289 & 80.67 & 22.56 & 23.67 \\
5 & $\mathrm{Ni}$ & 0.811 & 4.619 & 2.269 & 2.041 \\
6 & $\mathrm{Cu}$ & 1.105 & 53.16 & 15.24 & 9.637 \\
7 & $\mathrm{Zn}$ & 1.593 & 43.03 & 10.66 & 9.008 \\
8 & $\mathrm{Co}$ & 0.887 & 9.576 & 3.205 & 3.008 \\
9 & $\mathrm{Fe}$ & 4.992 & 14.99 & 8.277 & 8.524 \\
10 & $\mathrm{Mn}$ & 2.621 & 18.17 & 6.735 & 6.864 \\
11 & $\mathrm{Mg}$ & 7.686 & 132.1 & 68.09 & 41.03 \\
12 & $\mathrm{Na}$ & 2.170 & 5.601 & 3.331 & 3.434 \\
13 & $\mathrm{Ca}$ & 8.400 & 105.3 & 58.41 & 37.25 \\
14 & $\mathrm{~K}$ & 0.229 & 2.349 & 1.670 & 0.965 \\
Average of CF & 7.66 & 55.92 & 27.95 & 21.83 \\
\hline
\end{tabular}

4.6 A weighted average of pollution index

A weighted average of pollution index was also calculated for various elements in the study area according to methodology defined by Qingiie and Jun (2008). The decreasing trend of mean weighted pollution index of toxic and heavy metals were in the order of $\mathrm{Cr}>\mathrm{Pb}>\mathrm{Zn}>\mathrm{Cu}>\mathrm{Cd}>\mathrm{Ni}>\mathrm{Co}$, while the decreasing trend for major elements were $\mathrm{Mg}>\mathrm{Ca}>\mathrm{Fe}>$ $\mathrm{Mn}>\mathrm{Na}>\mathrm{K}$. The mean, minimum, and maximum $\mathrm{PIw}_{\text {avg }}$ are given in Table 5. The weighted values varied from 1 to 5 on the basis of their toxicity. On the basis of higher toxicity of $\mathrm{Cd}$, it is ranked as 5, while $\mathrm{K}$ is ranked 1 because of its low or no toxicity. The minimum, maximum, and mean values of $\mathrm{PIW}_{\text {avg }}$ were 432.1, 2537, and 1308, respectively (Table 5).

The statistical analysis revealed that the geo-accumulation index, ecological risk index, and contamination factor were correlated with each other, while enrichment factors mostly fluctuated with other statistical methods.

In the case of $\mathrm{Cr}$, the geo-accumulation index, ecological risk index, and contamination factor showed high values according to their grades or degrees, while enrichment factor showed a low value for $\mathrm{Cr}$ according to their own grades. According to geo-accumulation index, contamination factor and ecological risk factor for cadmium showed low risk values, while enrichment factor reveal that the $\mathrm{Cd}$ was enriched in the study area (Table 6).

According to the geo-accumulation index, ecological risk index, and contamination factor, potassium was observed in low category, while enrichment factor showed an enriched value for potassium. The statistical analysis, geo-accumulation index, ecological risk index, and contamination factor were mostly correlated with each other and did not show any discrepancy

Table 5 Weighted average pollution index for the soil of GAIE and surrounding areas

\begin{tabular}{llllll}
\hline $\mathrm{S} / \mathrm{N}$ & Parameters & $\begin{array}{l}\text { Weighted } \\
(\text { Wi) }\end{array}$ & $\begin{array}{l}\text { Min } \\
(\mathrm{PiWi})\end{array}$ & $\begin{array}{l}\text { Max } \\
(\mathrm{PiWi})\end{array}$ & $\begin{array}{l}\text { Mean } \\
(\mathrm{PiWi})\end{array}$ \\
\hline 1 & $\mathrm{Cr}$ & 5 & 345.5 & 1520 & 942.5 \\
2 & $\mathrm{Cd}$ & 5 & 1.61 & 46.79 & 11.33 \\
3 & $\mathrm{~Pb}$ & 5 & 36.45 & 403.3 & 112.8 \\
4 & $\mathrm{Ni}$ & 4 & 3.24 & 18.47 & 9.08 \\
5 & $\mathrm{Cu}$ & 3 & 3.32 & 159.4 & 45.71 \\
6 & $\mathrm{Zn}$ & 1 & 1.59 & 43.02 & 10.66 \\
7 & $\mathrm{Co}$ & 2 & 1.77 & 19.15 & 6.41 \\
8 & $\mathrm{Fe}$ & 3 & 14.98 & 44.97 & 24.83 \\
9 & $\mathrm{Mn}$ & 2 & 5.24 & 36.35 & 13.47 \\
10 & $\mathrm{Mg}$ & 1 & 7.68 & 131.9 & 68.09 \\
11 & $\mathrm{Na}$ & 1 & 2.17 & 5.60 & 3.33 \\
12 & $\mathrm{Ca}$ & 1 & 8.4 & 105.3 & 58.41 \\
13 & $\mathrm{~K}$ & 1 & 0.229 & 2.35 & 1.67 \\
$\mathrm{PIw}$ & & & 432.1 & 2537 & 1308 \\
\hline
\end{tabular}


Table 6 Comparison and correlation of statistical methods with elemental concentration

\begin{tabular}{|c|c|c|c|c|}
\hline Metals & $\begin{array}{l}\text { Geo-accumulation } \\
\text { index }\end{array}$ & $\begin{array}{l}\text { Enrichment } \\
\text { factor }\end{array}$ & $\begin{array}{l}\text { Ecological } \\
\text { risk index }\end{array}$ & $\begin{array}{l}\text { Contamination } \\
\text { factor }\end{array}$ \\
\hline $\mathrm{Cr}$ & $\begin{array}{l}\text { Severely extreme } \\
\text { polluted }\end{array}$ & Depleted & $\begin{array}{l}\text { Very high } \\
\text { risk }\end{array}$ & Polluted \\
\hline $\mathrm{Cd}$ & Unpolluted & Enriched & Low risk & Unpolluted \\
\hline $\mathrm{Pb}$ & $\begin{array}{l}\text { Moderately } \\
\text { polluted }\end{array}$ & Depleted & Considerable & Polluted \\
\hline $\mathrm{Ni}$ & Unpolluted & Enriched & Low risk & Polluted \\
\hline $\mathrm{Cu}$ & Severely polluted & Enriched & Moderate & Polluted \\
\hline $\mathrm{Zn}$ & Moderate & Enriched & Low risk & Polluted \\
\hline Co & Slightly polluted & Enriched & Low risk & Polluted \\
\hline $\mathrm{Fe}$ & Moderate polluted & Depleted & Low risk & Polluted \\
\hline $\mathrm{Mn}$ & Moderate polluted & Depleted & Low risk & Polluted \\
\hline $\mathrm{Mg}$ & $\begin{array}{l}\text { Severely extreme } \\
\text { polluted }\end{array}$ & Depleted & Moderate & Polluted \\
\hline $\mathrm{Na}$ & Slightly & Depleted & Low risk & Polluted \\
\hline $\mathrm{Ca}$ & Severely extreme & Depleted & Moderate & Polluted \\
\hline $\mathrm{K}$ & Unpolluted & Enriched & Low risk & Unpolluted \\
\hline
\end{tabular}

as compared to enrichment factor. According to Table 6, the geo-accumulation index, ecological risk index, and contamination factor were considered suitable methods for evaluation of metals toxicity as well as their health and ecological risk identification. Whereas the enrichment was also found to be a suitable method, it is appropriate for determining mineral economical values rather than toxicity (Stolz et al. 2006).

\section{Discussions}

The rapid growths of economic development, globalization, and industrialization have a major role in ecological destruction. Through these developments, various types of pollutants (i.e., heavy and major elements) are released, which continuously affect soil and water quality through various means, i.e., pesticides, wastewater irrigation, solid waste disposal, etc. (Banat et al. 2005). For effective monitoring of aquatic environment, soil is the most sensitive and active indicator. Its contamination received serious attention in both developing and developed nations (Nicholson et al. 2003; Zhang et al. 2007).

The comparative study (Table 7) showed that the $\mathrm{Pb}$ concentrations in this study were high compared with other reports except one by Ali and Malik (2011). Lead is mainly present in organic and inorganic compounds. It has a wide range of toxic effects, including psychopathic effect (damaging of central and peripheral nervous system), cardiac problem, and inhibition in the blood production (Morais et al. 2012). The concentration of Ni observed during the study was higher than most of the other studies (Table 7). The anthropogenic sources of $\mathrm{Ni}$ are nickel-cadmium batteries and ghee industries (Hussain et al. 2014). Nickel is considered as a nasty, toxic, and carcinogenic metal. Upon high consumption, it generally stuck on DNA, protein, and blood. It also causes allergy and dermatitis (Thyssen et al. 2007). Cobalt concentration is also high and has a vital role in vitamins B12 found in tissues. The high accumulation of Co in human tissue can cause bronchial asthma, cardiovascular diseases (anemia), eczema, and destruction of thyroid gland. It is also considered as genotoxic and carcinogenic (Ahmad et al. 2014; Manzoor et al. 2006).

In the target area, the concentration of $\mathrm{Cr}$ is higher than that reported in most of the national and international literatures (Table 7). Its concentration in the reference area is also higher than the majority of selected studies. This high concentration in the target area (industrial zones) can be attributed to anthropogenic inputs and mostly associated with metallurgical

Table 7 Comparison of present study concentration $(\mathrm{mg} / \mathrm{kg})$ with other national and international studies

\begin{tabular}{llllllllllllll}
\hline $\mathrm{Cr}$ & $\mathrm{Cd}$ & $\mathrm{Pb}$ & $\mathrm{Ni}$ & $\mathrm{Cu}$ & $\mathrm{Zn}$ & $\mathrm{Co}$ & $\mathrm{Fe}$ & $\mathrm{Mn}$ & $\mathrm{Mg}$ & $\mathrm{Na}$ & $\mathrm{Ca}$ & $\mathrm{K}$ & References \\
\hline 26.5 & 0.34 & 22.8 & 20.9 & 22.5 & 53 & 7.1 & 13,608 & 295 & - & - & - & - & Mico et al. 2007 \\
30.6 & 2.8 & 15.6 & 13.4 & 20.3 & 43.2 & 156 & & & - & - & - & - & Sharma et al. 2007 \\
59 & - & 24 & 24.3 & 21.9 & 69.8 & 11.2 & - & 547 & - & - & - & - & Wu et al. 2010 \\
- & 3.4 & 209 & 90.8 & 17.4 & 1658 & 16.3 & 40,694 & - & 16,014 & 297 & 36,412 & 4645 & Ali and Malik 2011 \\
146 & 2.0 & 117 & 99 & 193 & 361 & 193 & 25,080 & $\mathrm{cbd}$ & 7153 & 4645 & 9792 & 12,146 & Muhammad et al. 2011, \\
21.0 & 1.6 & 2.5 & - & 10.2 & 23.8 & 10.3 & 12,784 & 393 & 2769 & 999 & 27,531 & 737 & Iqbal and Shah 2011 \\
32.6 & 1.9 & 47.0 & - & 18.1 & 35.5 & 3.5 & 1241 & 343 & 906 & 92.3 & 3520 & 1489 & Shah et al. 2011 \\
42.8 & 0.7 & 13.3 & 34.0 & 16.1 & 41.7 & 15.6 & 40,111 & 798 & 19,640 & 20,367 & 69,673 & 19,842 & Jabeen 2013 \\
271 & 1.0 & 205 & 46 & 185.7 & 555 & - & 495.1 & 46.8 & - & - & - & - & Jaboobi et al. 2014 \\
475.5 & 0.45 & 217.5 & 78.1 & 229.8 & 907.9 & 0.55 & 45.7 & 543.8 & - & - & - & - & Ahmad et al. 2014 \\
301.6 & 8.8 & 152 & 58 & 144.8 & 359.4 & 32.5 & 1097.6 & 2508 & 786.5 & 2572 & 4088.9 & 689.8 & Present Study (Target area) \\
93.6 & 6.1 & 35.5 & 55.9 & 59.1 & 116.4 & 24.1 & 644.3 & 1112.3 & 549.4 & 1275.1 & 2364.4 & 995.2 & Present study (reference area) \\
\hline
\end{tabular}


industries, such as stainless steel, metal plating, metal alloys, and chromium alloys industries. These industries usually release a vast amount of chromium to environment, which has drastic effects on human health as the high consumption of $\mathrm{Cr}$ causes asthma, chronic pharyngitis, erythema, and swelling of skin (Ipeaiyeda and Onianwa 2011). It also causes renal effect, carcinogenic, hepatic problems (liver cell and necrosis), gastrointestinal effect, and cardiovascular effect in the human body (Jaboobi et al. 2014; Lenntech 2004).

In soil, $\mathrm{Fe}$ concentration is high, but it is lower than that of the other selected studies (Table 7). Iron is essential for photosynthesis (chlorophyll formulation) if present in normal amount, but its deficiency cause chlorosis in plants. In human being, excessive $\mathrm{Fe}$ causes cardiovascular problems, hepatic effects, destruction of DNA chain, etc. (Brewer 2010).

The $\mathrm{Zn}$ concentration in both reference and target areas were higher than that of the national and international studies except Ali and Malik (2011). The high level of Zn can cause stunted growth and chlorosis in plants. While in young plant, the size of internodes become short, and leaves adopt whitish color (Brewer 2010). The high exposures to $\mathrm{Zn}$ compounds are harmful to human health. Its high consumption can deregulate homeostasis, affect the molecular regulation of cells (brain cell death), and affect normal function of protein. Zinc deficiency also has a vital impact on growth, neuronal development, and body immunity (Wang et al. 2012). Among the major elements, $\mathrm{Cu}$ can interfere with adrenal and thyroid gland function. Besides this, it also causes hypoglycemia, mental disorders (depression), reproductive disease (premenstrual syndrome), anemia, and anxiety (Singh et al. 2004).

Major element concentrations are comparable with those of the other national and international studies (Table 7). The results reveal that the concentrations of major elements are almost similar to those from the other national and international studies. Major elements are more harmful in compound form than elemental form. These elements were found in high concentration in the studied soil, which could be taken up by the plants and hence ultimately enter into food chain causing significant health impacts in human body (Adakole and Abolude 2009). Among the major elements, manganese caused spastic gait, sleepiness, paralysis emotional disturbance, and languor (Bohn et al. 2001). The high consumption of sodium and potassium compounds causes health problem such as liver and kidney stress, feeling of frustration, intolerance of glucose, frustration feeling, hostility, and resentment (WHO 2004).

\section{Conclusions}

On the basis of multiapproach analysis, including geoaccumulation index, enrichment factor, ecological risk index, and pollution load index, it has been noticed that the soil of the
Gadoon Amazai Industrial Estate is highly affected by the release of effluents containing toxic and heavy metals from the various industries. These toxic metals can cause environmental problems in ecosystem of the area due to the release of toxic and heavy metals from the contaminated soil to the ground water system and also in the plants and vegetation grown in the soil. This alarming situation should be regularly monitored for health-related problems in the inhabitants of the area. It is, therefore, strongly recommended that phyto- or bioremedial measures should be considered by local and international agencies in order to minimize the extent of accumulated pollution loads.

Acknowledgments The Director of the National Centre of Excellence in Geology is highly acknowledged for providing laboratory facilities, financial support for fieldwork, and encouragement during the entire period of research. Mohammad Tariq (Lab Technician) is thanked for his assistance during analytical work.

Open Access This article is distributed under the terms of the Creative Commons Attribution License which permits any use, distribution, and reproduction in any medium, provided the original author(s) and the source are credited.

\section{References}

Adakole JA, Abolude DS (2009) Studies on effluent characteristics of a metal finishing company, Zaria-Nigeria. Res J Environ Earth Sci 1(2):54-57

Ahmad K, Khan ZI, Ashfaq A, Ashraf M, Yasmin S (2014) Assessment of heavy metal and metalloid levels in spinach (Spinacia oleraceal.) grown in wastewater irrigated agricultural soil of Sargodha, Pakistan. Pak J Bot 46(5):1805-1810

Ali SM, Malik RN (2011) Spatial distribution of metals in top soils of Islamabad City, Pakistan. Environ Monit Assess 172:1-16

Ameh EG, Kolawole MS, Imeokparia EG (2011) Using factor-cluster analysis and Enrichment methods to evaluate impact of cement production on stream sediments around Obajana cement factory in Kogi State, North Central Nigeria, Pelagia research library. Adv Appl Sci Res 2(1):76-89

Amin N, Ibrar D, Sultan Alam S (2014) Heavy metals accumulation in soil irrigated with industrial effluents of Gadoon Industrial Estate, Pakistan and its comparison with fresh water irrigated soil. J Agric Chem Environ 3(2):80-87

Atgn RS, El-Agha O, Zararsiz A, Kocatas A, Parlak H, Tuncel G (2000) Investigation of the sediment pollution in Izmir Bay: trace elements. Spectrochim Acta B 55:1151-1164

Baig ZM (1996) Environmental geochemistry of water, rocks and soil of Gadoon and surrounding area district Swabi, North West Frontier Pakistan (NWFP), Pakistan. M.Phil Thesis, National Centre of Excellence in Geology, University of Peshawar

Banat KM, Howari FM, Al-Hamada AA (2005) Heavy metals in urban soils of central Jordan; should we worry about their environmental risks. Environ Res 97:258-273

Bohn HL, Neal BL, Connor GA (2001) Soil chemistry. Wiley, New York

Brewer GJ (2010) Copper toxicity in the general population. Clin Neurol Physiol 121(4):459-460 
Cabrera F, Clemente L, Barrientos DE et al (1999) Heavy metal pollution of soils affected by the Guadiamar toxic flood. Sci Total Environ 242(3):117-129

Caeiro S, Costa MH, Ramos TB (2005) Assessing heavy metal contamination in Sado Estuary sediment; an index analysis approach. Ecol Indic 5:151-169

Fagbote EO, Olanipekun EO (2010) Evaluation of the status of heavy metal pollution of soil and plant (Chromolaena odorata) of Agbabu Bitumen Deposit Area, Nigeria. Am-Eur J Sci Res 5(4):241-248

Filipssona AF, Hanbergb A, Victorinb K, Warholmb M, Wallen M (2007) Assessment factors; applications in health risk assessment of chemicals. Environ Res 104:108-127

Flaten, TP, Steinnes E (1999) Soil and fresh water. General applied and systems toxicology, Wiley Online Library

Gaballah I, Kilbertus G (1998) Recovery of heavy metal ions through decontamination of synthetic solutions and industrial wastewater using modified barks. J Geochem Explor 62:243-251

Grath DM, Zhang C, Carton OT (2004) Geo-statistical analyses and hazard assessment on soil lead in silver mines area, Ireland. Environ Pollut 127:239-248

Hakanson L (1980) An ecological risk index for aquatic pollution control; a sedimentological approach. Water Res 14:975-1001

Harikumar PS, Nasir UP, Rahman MP (2009) Distribution of heavy metals in the core sediments of a tropical wetland system. Int J Environ Sci Technol 6(2):225-232

Hussain R (2014) Physico-chemical analysis of industrial effluents of Gadoon Amazai Industrial Estate and their environmental impacts on the soil and groundwater of surrounding area, Swabi, Khyber Pakhtunkhwa. M.Phil Thesis, National Centre of Excellence in Geology, University of Peshawar

Hussain F, Ahmad M, Durani MJ, Shaheen G (1993) Phytosociology of the vanishing subtropical dry deciduous forest in district Swabi, Pakistan, II. A community analysis. Pak J Bot 25(1):51-66

Hussain A, Dipietro JA, Pogue KA, Ahmed I (2004) Geologic map of 43B degree sheet of NWFP, Pakistan. Geologic map series, Geological survey of Pakistan, Map No. 11

Hussain R, Ahmad W, Nafees M, Hussain A (2014) Optimization of wastewater treatment process in industry "a case study of Hattar Industrial Estate Haripur”. Pak J Anal Environ Chem 15(1):28-34

Huu HH, Rudy S, Damme AV (2010) Distribution and contamination status of heavy metals in estuarine sediments near CauOng Harbor Ha long Bay, Vietnam. Geol Belg 13(1-2):37-47

Ipeaiyeda AR, Onianwa PC (2011) Pollution effect of food and beverages effluents on the Alaro river in Ibadan city, Nigseria. Bull Chem Soc Ethiop 25(3):347-360

Iqbal J, Shah MH (2011) Distribution, correlation and risk assessment of selected metals in urban soils from Islamabad, Pakistan. J Hazard Mater 192:887-898

Jabeen S (2013) Environmental geochemistry of Attock and Haripur basins, Pakistan. Ph.D thesis, National Centre of Excellence in Geology, University of Peshawar, Pakistan

Jaboobi M, Zouahri A, Tijane MH, Housni A, Mennane Z, Yachou H, Bouksaim M (2014) Evaluation of heavy metals pollution in groundwater, soil and some vegetables irrigated with wastewater in the Skhirat region Morocco. J Mater Environ Sci 5(3):961-966

Jeffery PG, Hutchison D (1986) Chemical methods of rock analysis. Pargamon Press, Oxford

Kazi TG, Arain MB, Jamali MK, Jalbani N, Afridi HI, Sarfraz RA, Baig JA, Shah AQ (2009) Assessment of water quality of polluted lake using multivariate statistical techniques. Ecotoxicol Environ Saf 72: 301-309

Khan S, Cao Q, Zheng YM, Huang YZ, Zhu YG (2008) Health risks of heavy metals in contaminated soils and food crops irrigated with wastewater in Beijing, China. Environ Pollut 152:686-692
Khan S, Ahmad I, Shah MT, Rehman SS, Khaliq A (2009) Use of constructed wetland for the removal of heavy metals from industrial wastewater. J Environ Manag 90:3451-3457

Lenntech K (2004) Water treatment and air purification. Published by Rotter Dam Seweg, Netherlands

Lokeshwari H, Chandrappa GT (2006) Heavy metals content in water; hyacinth water and sediments of Lalbagh Tank, Bangalore, India. J Environ Sci Eng 48(3):183-188

Macalalad E, Bayoran R, Ebarvia B, Rubeska I (1988) A concise analytical scheme for 16 trace elements in geochemical exploration samples using exclusively AAS. J Geochem Explor 30:167-177

Manzoor S, Munir H, Shah N, Shaheen A, Jaffar M (2006) Multivariate analysis of trace metals in textile effluents in relation to soil and groundwater. J Hazard Mater 137(1):31-37

Mico C, Peris M, Recatala L, Sanchez J (2007) Baseline values for heavy metals in agricultural soils in an European Mediterranean region. Sci Total Environ 378:13-17

Morais S, Costa FG, Pereira ML (2012) Heavy metals \& human health. In: Oosthuizen J (ed) Environmental health - emerging issues and practice, 1st Ed. InTech, Rijeka, pp 227-246

Muhammad S, Shah MT, Khan S (2011) Health risk assessment of heavy metals and their source apportionment in drinking water of Kohistan regions, Northern Pakistan. Microchem J 98:334-343

Nasrullah, Naz R, Bibi H, Iqbal M, Durrani MI (2006) Pollution load in industrial effluent and ground water of Gadoon Amazai industrial estate (GAIE) Swabi, NWFP. J Agri Biolog Sci 1(3):18-24

Nicholson FA, Smith SR, Alloway BJ, Smith C, Chambers BJ (2003) An inventory of heavy metals inputs to agricultural soils in England and Wales. Sci Total Environ 311:205-219

Qingjie G, Jun D (2008) Calculating pollution indices by heavy metals in ecological geochemistry assessment; a case study in parks of Beijing. J Chin Univ Geosci 19(3):23-41

Sarhad Development Authority (SDA) (2009) Department of Planning and Development, Government of Pakistan

Shah MH, Iqbal J, Shaheen N, Nadeem K, Choudhary MA, Akhter G (2011) Assessment of background levels of trace metals in water and soil from a remote region of Himalaya. Environ Monit Assess 184(3):1243-1252

Sharma RK, Agrawal M, Marshall F (2007) Heavy metal contamination of soil and vegetables in suburban areas of Varanasi, India. Ecotoxicol Environ Saf 66:258-266

Singh KP, Mohan D, Sinha S, Dalwani R (2004) Impact assessment of treated/untreated wastewater toxicants discharged by sewage treatment plants on health, agricultural, and environmental quality in the wastewater disposal area. Chemosphere 55:227-255

Steinnes E, Solber W, Peterson HM, Wren CD (1989) Heavy metals pollution by long range atmospheric transport in natural soil of southern Norway. Water Air Soil Pollut 45:207-218

Stolz AJ, Jochum KP, Spettel B, Hofmaan AW (2006) Fluid and melt related enrichment in the subarc mantle: evidence from $\mathrm{Nb} / \mathrm{Ta}$ variation in island arc basalt. Geology 24:587-590

Sundaray SK, Nayak BB, Lin S, Bhatt D (2011) Geochemical speciation and risk assessment of heavy metals in the river estuarine sediments; a case study of Mahanadi basin, India. J Hazard Mater 186:18371846

Sutherland RA (2000) Bed sediment and associated trace metals in an urban stream, Oahu, Hawaii. Environ Geol 39:611-627

Thyssen JP, Limeberg A, Menne T, Johansen JD (2007) The epidemiology of contact allergy in the general population, prevalence and main finding. Dermatitis 57(5):287-299

Tomlinson DC, Wilson JG, Harris CR, Jeffery DW (1996) Problems in the assessment of heavy metals levels in estuaries and the formation of a pollution index. Helgoländer Meeresun 33(1-4):566-575 
Wang Y, Qiao M, Liu Y, Zhu Y (2012) Health risk assessment of heavy metals in soils and vegetables from wastewater irrigated area, Tianjin, Beijing, China. J Environ Sci 24(4):690-698

World Health Organization (2004) Guidelines for drinking water quality. World Health Organization (WHO), 3rd edn, vol 1. World Health Organization, Geneva

Wu S, Xia X, Chen X, Zhou C (2010) Levels of arsenic and heavy metals in the rural soils of Beijing and their changes over the last two decades. J Hazard Mater 179(3):860-868
Yang Q, Xu Y, Liu S, He J, Long F (2011) Concentration and potential health risk of heavy metals in market vegetables in Chongqing, China. Ecotoxicol Environ Saf 74(6):1664-1669

Yisa NJ, John O, Christian J, Onoyima C (2012) Assessment of toxic levels of some heavy metals in road deposited sediments in Suleja. Am J Chem 2(2):34-37

Zhang LP, Ye X, Feng H (2007) Heavy metal contamination in Western Xiamen Bay sediments and its vicinity, China. Mar Pollut Bull 54: 974-982 